\author{
TADEUSZ WOLSZA \\ Instytut Historii PAN, Warszawa
}

\title{
ZWIĄZKI MIĘDZY POLITYKĄ I SPORTEM W POLSKIEJ RZECZYPOSPOLITEJ LUDOWEJ
}

Artur Pasko, pracownik naukowy Uniwersytetu w Białymstoku, to w chwili obecnej jeden z najbardziej rozpoznawalnych historyków zajmujących się powojennymi dziejami sportu w Polsce, przede wszystkim w kontekście relacji z małą i wielką polityką. Moim zdaniem Autor recenzowanej pracy Sport wyczynowy w polityce państwa 1944-1989 jest w chwili obecnej wyjątkowo rzetelnym kontynuatorem badań, które przed kilku laty z tak dużym powodzeniem rozpoczęli dla okresu po II wojnie światowej Marek Ordyłowski ${ }^{1}$, Leonard Szymański $^{2}$ i Piotr Godlewski ${ }^{3}$ oraz dla lat wcześniejszych Bogdan Tuszyński ${ }^{4}$, Dobiesław Dudek ${ }^{5}$, Robert Gawkowski ${ }^{6}$ i Ryszard Wryk ${ }^{7}$.

\footnotetext{
* Na marginesie: Artur Pasko, Sport wyczynowy w polityce państwa 1944-1989, Kraków 2012, Wydawnictwo Avalon, ss. 535.

${ }^{1}$ Wskazałbym tu na kilka artykułów M. Ordyłowskiego z jego pracy Szkice z dziejów kultury fizycznej, Zielona Góra 2005, m.in. Wielkie imprezy sportowe jako kampanie propagandowe PZPR w latach 1949-1956, Polityczne aspekty kultury fizycznej na wsi dolnoślaskiej 19451956, Stalinizm w sporcie, Sport państwowy - sport zawodowy. Lata pięćdziesiąte w rozwoju sportu w PRL, Whołdzie Bierutowi. Obchody 60-lecia urodzin Bolestawa Bieruta w sporcie polskim.

${ }^{2}$ L. Szymański, Kultura fizyczna i turystyka w polityce Polski Ludowej 1944-1989, Wrocław 2004; idem, M. Ordyłowski, Kadry - „Oko, ucho i ręka” władzy ludowej w sporcie polskim 1945-1989, w: Wokół historii i polityki. Studia z dziejów XIX i XX wieku dedykowane profesorowi Wojciechowi Wrzesińskiemu, red. S. Ciesielski i in., Toruń 2004, s. 601-613.

${ }^{3}$ P. Godlewski, Sport w Polsce na tle politycznej rzeczywistości lat 1944-1956, Poznań 2006; idem, Sport w stużbie PRL, w: Sport i polityka w dwudziestowiecznych państwach totalitarnych $i$ autorytarnych, red. T. Gąsowski, S. Bielański, Kraków 2009, s. 21-73.

${ }^{4}$ B. Tuszyński, Księga sportowców polskich ofiar II wojny światowej 1939-1945, Warszawa 1999.

${ }^{5}$ D. Dudek, Józef Piłsudski wobec problemów kultury fizycznej (1910-1935), Kraków 2004.

${ }^{6}$ R. Gawkowski, Encyklopedia klubów sportowych Warszawy i jej najbliższych okolic w latach 1918-39, Warszawa 2007; J. Bułanow, 11 Czarnych Koszul - moje wspomnienia, oprac. R. Gawkowski, Warszawa 2011; R. Gawkowski, Futbol dawnej Warszawy, Warszawa 2013.

${ }^{7}$ R. Wryk, Początki ruchu olimpijskiego w Polsce, Poznań 2012.
} 
Od 2005 r. Pasko regularnie wysyła do innych badaczy oraz czytelników wyraźny sygnał, iż podjął badania dotyczące wzajemnych relacji pomiędzy polityką i sportem w powojennej Polsce. Wówczas bowiem opublikował pierwszy tekst z tego zakresu pt. Świat sportu wobec interwencji państw Układu Warszawskiego w Czechosłowacji w 1968 r. ${ }^{8}$ Nie dalej jak rok później w „Tekach Archiwalnych” pomieścił kilka dokumentów na temat mistrzostw Europy w boksie, które odbyły się w Warszawie w $1953 \mathrm{r}$. i były obiektem ogromnego zainteresowania nie tylko kibiców, ale i polityków z Polskiej Zjednoczonej Partii Robotniczej, z uwagi na wyjątkowo drażliwy polsko-sowiecki kontekst tej rywalizacji, wzmocniony dodatkowo śmiercią Józefa Stalina ${ }^{9}$. Pragnę wszakże w tym miejscu zauważyć, że część tej dokumentacji była już wcześniej opublikowana przez Jacka Wojsława w opracowaniu pt. Dokumenty Wydziału Propagandy i Agitacji KC PZPR dotyczace problematyki sportowej jako źródło poznania rzeczywistości społecznej Polski lat 1949-1954 ${ }^{10}$. Obok materiałów na temat boksu Wojsław pomieścił również w przywołanej publikacji i inne nieznane wcześniej dwa dokumenty dotyczące Wyścigu Pokoju, nota bene, powtórnie po kilku latach opublikowane przez Paskę w wyborze źródeł na temat Wyścigu Pokoju ${ }^{11}$.

W latach 2007-2012 Autor pracy przygotował kolejne (około trzydziestu) studia i artykuły z zakresu sportu i polityki po $1945 \mathrm{r}$. Ukazały się one w pracach zbiorowych oraz w czasopismach ogólnopolskich i regionalnych. Po latach w większości weszły one we fragmentach do recenzowanej tu książki. Z tych blisko trzydziestu studiów i artykułów zwróciłbym uwagę na kilka, które wprowadziły do obiegu naukowego szereg nowych faktów, danych i interpretacji. Przede wszystkim wskazałbym na pionierskie opracowanie pt. Polski Komitet Olimpijski w okresie stalinizmu ${ }^{12}$. Dalej zaś należy wymienić: Kontakty sportowe Polski i Czechosłowacji w latach 1948-1956 ${ }^{13}$, Współzawodnictwo socjalistyczne w sporcie w latach $1950-1955^{14}$ oraz Kobieta-sportowiec w propagandzie Polski Ludowej w okresie stalinizmu w świetle „Trybuny Ludu”"15.

${ }^{8}$ A. Pasko, Świat sportu wobec interwencji państw Układu Warszawskiego w Czechosłowacji w 1968 r., DN 2005, 3, s. 83-95.

${ }^{9}$ Idem, Mistrzostwa Europy w boksie w 1953 r. w ocenie władz partyjnych i sportowych, „Teki Archiwalne” 9, 2006, s. 273-285.

${ }^{10} \mathrm{~J}$. Wojsław, Dokumenty Wydziału Propagandy i Agitacji KC PZPR dotyczace problematyki sportowej jako źródło poznania rzeczywistości społecznej Polski lat 1949-1954, „Polska 1944/45-1989. Studia i materiały" 4, 1999, s. 339-352.

${ }^{11}$ A. Pasko, Wyścig Pokoju w dokumentach władz partyjnych i państwowych 1948-1989, Kraków 2009.

${ }^{12}$ Idem, Polski Komitet Olimpijski w okresie stalinizmu, DN 2010, 1, s. 105-120.

${ }^{13}$ Idem, Kontakty sportowe Polski i Czechosłowacji w latach 1948-1956, w: Między przymusowa przyjaźnią a prawdziwa solidarnością. Czesi - Polacy - Słowacy, cz. 2, red. P. Blažek, P. Jaworski, Ł. Kamiński, Warszawa 2009, s. 163-171.

${ }^{14}$ Idem, Współzawodnictwo socjalistyczne w sporcie w latach 1950-1955, w: Wspótzawodnictwo pracy $w$ życiu gospodarczym, społeczno-politycznym i propagandzie PRL, red. B. Tracz, Katowice 2008, s. 201-207.

${ }^{15}$ Idem, Kobieta-sportowiec w propagandzie Polski Ludowej w okresie stalinizmu w świet- 
Temat, którym zajmuje się białostocki historyk, nie jest nowy, wszak nie dalej jak siedem lat temu wątek ten podniósł Godlewski w przywołanej w przypisie trzecim pracy Sport w Polsce na tle politycznej rzeczywistości lat 1944-1956. Recenzowana tu praca ma jednak charakter nowatorski z kilku powodów. Po pierwsze, Pasko rozszerzył chronologię o lata 1956-1989. Po drugie, znacząco wzbogacił bazę źródłową dla omawianego tematu, w tym m.in. o dokumentację zagraniczną. Po trzecie, podniósł szereg nowych wątków, których nie uwzględnił wcześniej Godlewski oraz inni badacze zagadnienia (przede wszystkim mam tu na myśli m.in. obszernie omówione zagadnienie sportowców amatorów w dziejach sportu wyczynowego w PRL, również w kontekście zagadnień ekonomicznych, np. pensje, nagrody, diety, honoraria itp.). Sprawy te szczegółowo rozwinę w dalszej części artykułu. Jak już zasygnalizowałem, pierwszą zaletę pracy stanowi jej chronologia. Pasko to w chwili obecnej jeden z nielicznych badaczy dziejów sportu w Polsce, który wykroczył poza rok 1956. Natomiast jeśli chodzi o relacje sport-polityka w ujęciu ogólnopolskim i w skali całego bloku wschodniego znajdującego się pod sowiecką dominacją, jest niewątpliwie niezagrożonym pionierem. Można więc skonstatować bez cienia najmniejszej wątpliwości, że temat książki został sformułowany trafnie i wypełnia lukę w krajowej historiografii. Kolejną zaletą recenzowanej publikacji jest baza źródłowa. Autor postawił sobie w tym wypadku poprzeczkę bardzo wysoko. Rzecz nie dotyczy tylko licznych archiwów krajowych, do których dotarł w trakcie kwerendy. Badania przeprowadził również w zbiorach Archiwum Międzynarodowego Komitetu Olimpijskiego w Lozannie, w dziale dotyczącym wymiany korespondencji pomiędzy Polskim Komitetem Olimpijskim i Międzynarodowym Komitetem Olimpijskim w latach 1919-1958. Spośród placówek krajowych odwołał się do dokumentacji zdeponowanej w Archiwum Akt Nowych, Archiwum Ministerstwa Spraw Zagranicznych, Archiwum Ministerstwa Edukacji Narodowej, Archiwum Instytutu Pamięci Narodowej, Centralnego Archiwum Wojskowego oraz kilku archiwów państwowych, m.in. w Białymstoku, Katowicach, Krakowie i Poznaniu. Ze zbiorów prywatnych swoje kolekcje udostępnili Autorowi: Bolesław Kapitan, były szef Głównego Komitetu Kultury Fizycznej i Turystyki, oraz dziennikarz Lech Ufel. Część dokumentacji historyk sam wywołał. Mam tu na myśli kilkanaście wywiadów ze znanymi sportowcami i działaczami. Pasko dotarł m.in. do medalistów olimpijskich: Elżbiety Duńskiej-Krzesińskiej, Wojciecha Fortuny, Mariana Kasprzyka, Zbigniewa Pietrzykowskiego i Wojciecha Zabłockiego. Szeroko odwołał się do wspomnień wybitnych sportowców, trenerów i działaczy, w tym m.in. Kazimierza Górskiego, Jadwigi Jędrzejowskiej, Władysława Komara, Władysława Kozakiewicza, Zdzisława Krzyszkowiaka, Jerzego Kuleja, Włodzimierza Lubańskiego, Jana Mulaka, Jerzego Pawłowskiego, Feliksa Stamma, Ryszarda Szurkowskiego i Stanisława Terleckiego oraz do relacji komentatorów i dziennikarzy sportowych, np. Jerzego Zmarzlika i Tadeusza

le „Trybuny Ludu”, w: Kobieta a patriotyzm. Konteksty historyczno-pedagogiczne XX-XXI wieku, red. E.J. Kryńska, A. Szarkowska, U. Wróblewska, Białystok 2012, s. 201-213. 
Olszańskiego. Z prasy często przywołuje w naukowej narracji „Przegląd Sportowy” oraz „Trybunę Ludu”.

Z literatury naukowej wykorzystał przede wszystkim te publikacje, które traktują o tematyce zakreślonej w tytule pracy. Autor skonfrontował swoje ustalenia z wcześniejszymi badaniami zarówno historyków młodych, rozpoczynających swoją przygodę z Klio, jak i badaczy już uznanych oraz powszechnie określanych jako autorytety w omawianej tu sprawie. Mam tu na myśli ostatnio opublikowane cenne prace Artura Cegiełki ${ }^{16} \mathrm{i}$ Jakuba Ferenca ${ }^{17}$ oraz już wyżej wymienione publikacje: Godlewskiego, Ordyłowskiego, Szymańskiego i Tuszyńskiego.

Bibliografia pracy w sumie prezentuje się zaiste imponująco i na pierwszy rzut oka wydaje się niemal kompletna. Zauważyłem wszakże pewne luki i niekiedy, jak się wydaje, są one istotne. $Z$ ważniejszych prac z zakresu historii sportu zabrakło niewątpliwie pracy zbiorowej pt. Nieczysta gra. Tajne służby a piłka nożna ${ }^{18}$. To wręcz historia powojennej polskiej piłki nożnej widziana z perspektywy Służby Bezpieczeństwa. Nie mniej istotna wydaje się kolejna praca zbiorowa pt. Sport polonijny wczoraj i $d z i i^{19}$. Przy omówieniu karier działaczy sportowych z powojennego okresu, w kontekście ich działalności w dwudziestoleciu międzywojennym, można było odwołać się do wspomnianego już wcześniej kompendium wiedzy Gawkowskiego ${ }^{20}$. Dalej upomniałbym się o kilka drobnych tekstów opublikowanych w czasopismach Instytutu Pamięci Narodowej przez: Wacława Dubiańskiego ${ }^{21}$, Marcina Zwolskiego ${ }^{22}$ i Piotra Semkowa ${ }^{23}$. Kilka prac zbiorowych Autor wymienił w bibliografii, niestety, już nie zauważyłem, żeby później odwoływał się do ich zawartości w naukowej narracji, ze szkodą dla swoich rozważań. Wymienię w tym miejscu trzy przykłady.Z pracy Magia sportu i słowa zabrakło dwóch artykułów: Rafała Junga, Jan Ciszewski (1930-1982) - komentarz z dekady sukcesu oraz Grzegorza Wieczorka, Misja generała Kazimierza Glabisza podczas Igrzysk Olimpijskich w Rzymie (1960) ${ }^{24} . Z$ kolei z pracy zbiorowej pt. Sport i polityka $w$ dwudziestowiecznych państwach totalitarnych i autorytarnych. Autor pominął tekst Marcina Stasiaka Między "homo faber” a "homo ludens". Wzorzec bohatera sportowego w polskich mediach w latach 1949-1955. Nie muszę Autora specjalnie przekonywać, że jest to lektura obowiązkowa.

Przywołam jeszcze dwie prace z zakresu historii politycznej, w których tematyka sportowa splata się z innymi zagadnieniami. Mam tu na myśli książkę

${ }^{16}$ A. Cegiełka, Działania MSW wokót olimpijskich zmagań Moskwa '80, Warszawa 2011.

${ }^{17}$ J. Ferenc, Sport w służbie polityki. Wyścig Pokoju 1948-1989, Warszawa 2008.

${ }_{18}$ Nieczysta gra. Tajne służby a piłka nożna, red. S. Ligarski, G. Majchrzak, Chorzów 2012.

${ }^{19}$ Sport polonijny wczoraj i dziś, red. J. Chełmecki, Warszawa 2005.

${ }^{20}$ R. Gawkowski, Encyklopedia klubów sportowych Warszawy.

${ }^{21}$ W. Dubiański, Wyścig (nie)pokoju, „Biuletyn Instytutu Pamięci Narodowej” 2001, 11, s. 48-53.

${ }^{22}$ M. Zwolski, Lepsza piłka nożna niż Feliks Dzierżyński, „Biuletyn Instytutu Pamięci Narodowej" 2003, 10, s. 40-46.

${ }^{23}$ P. Semków, O niektórych dyscyplinach sportowych słów kilka..., „Biuletyn Instytutu Pamięci Narodowej" 2003, 10, s. 47-49.

${ }^{24}$ Magia sportu i słowa, red. A. Dobrowolska, M. Szczerbiński, G. Wieczorek, Gorzów Wlkp. 2008. 
Pawła Sowińskiego o obchodach świąt państwowych w powojennej Polsce ${ }^{25}$ i Daniela Wicentego o postawach dziennikarzy w $\mathrm{PRL}^{26}$. W tej drugiej negatywnymi bohaterami okazali się znani dziennikarze sportowi Jacek Żemantowski i Jerzy Mrzygłód. W końcu zgłaszam również sugestię, aby w przyszłości Pasko zapoznał się z maszynopisem pracy doktorskiej Jarosława Rokickiego na temat sportu żydowskiego w Polsce do 1950 r. Jej autoreferat ukazał się na łamach „Dziejów Najnowszych"27.

Omawiana tu praca składa się z sześciu rozdziałów. Cezury wewnętrzne stanowią wydarzenia z zakresu dziejów politycznych i historii sportu w Polsce: 1946 r., 1949 r., 1956 r., 1970 r.i 1980 r. Niejednokrotnie wydarzenia polityczne nakładają się na nie mniej istotne cezury historii sportu. Tak było np. w 1956 r. (polski Październik i olimpiada w Melbourne) oraz 1980 r. (polski Sierpień i powstanie „Solidarności" oraz olimpiada w Moskwie).

Pracę otwiera rozdział pt., Trudne, powojenne lata (1944-1946)”. Autor zauważył tu, iż w ówczesnej sytuacji społeczno-politycznej sowietyzowanego kraju największą wiedzą w zakresie działalności sportowej legitymowali się działacze Polskiej Partii Socjalistycznej, z uwagi na doświadczenia przedwojenne. Słusznie historyk podkreślił w tym miejscu,że to predysponowało socjalistów do kierowniczych stanowisk w resorcie, kosztem komunistów, którzy byli w tej dziedzinie zupełnymi laikami. O sile PPS świadczyło również to, że partia wydawała po wojnie m.in. „Przegląd Sportowy”. Socjaliści ponadto stali na stanowisku, iż należy oddzielić zagadnienia wychowania fizycznego i sportu wyczynowego od przysposobienia wojskowego. Ten stan rzeczy,jak zauważyłPasko, wywołał w kierownictwie Polskiej Partii Robotniczej różnego rodzaju inicjatywy obronne, których celem była np. próba skorumpowania kilku sportowców - z myślą wykorzystania ich w przyszłości do wspierania komunistycznych inicjatyw. Działacze PPR,jak skonstatował Autor, wbrew zamiarom PPS przeforsowali w końcu pomysł ulokowania w jednym urzędzie wychowania fizycznego i przysposobienia wojskowego. W argumentacji podkreślili,że w tym wypadku nawiązali do modelu przedwojennego. Zdaniem Autora czynili tak z dwóch powodów. Po pierwsze, ze względów strategicznych, z uwagi na to, że nad urzędem kontrolę przejęło wojsko, będące pod kierownictwem oficerów sowieckich i PPR. Po drugie, wedle opinii komunistów, co zostało podkreślone, zachowanie przedwojennego modelu miało zachęcić do współpracy m.in.ludzi kontestujących powojenny układ polityczny w kraju.

W tej części pracy Autor ustalił ponadto, że pod koniec 1945 r. w kraju rozwinęła działalność większość związków sportowych, z przedwojennymi działaczami w rolach głównych. Równolegle gros uwagi Pasko poświęcił środowisku wyczynowych sportowców. Omówił na podstawie istniejącej literatury przedmiotu, przede wszystkim na bazie badań Tuszyńskiego oraz własnych ustaleń,

${ }^{25}$ P. Sowiński, Komunistyczne święto. Obchody 1 maja w latach 1948-1954, Warszawa 2000.

${ }^{26}$ D. Wicenty, Załamanie na froncie ideologicznym. Stowarzyszenie Dziennikarzy Polskich od Sierpnia '80 do stanu wojennego, Gdańsk 2012.

${ }^{27} \mathrm{~J}$. Rokicki, Żydowski ruch sportowy i turystyczny w Polsce w pierwszej połowie XX wieku, DN 2007, 1. 
skalę strat w kręgach polskich sportowców najwyższej klasy (wśród ofiar wojny wymienił Janusza Kusocińskiego - symbol martyrologii sportowców, Tomasza Stankiewicza, Józefa Noja, Henryka Dobrzańskiego „Hubala”, Bronisława Czecha, Helenę Marusarzównę, Stanisława Gutta i wyliczył także sportowców i działaczy zamordowanych przez Sowietów). Z bardziej znanych ofiar pominął natomiast postać Eugeniusza Lokajskiego, olimpijczyka z Berlina (1936), fotografa Powstania Warszawskiego. Następnie zwrócił uwagę na tych, którzy przeżyli wojnę poza krajem i nie zdecydowali się z różnych powodów powrócić do Polski (tu jeden przykład lekkoatlety Stanisława Petkiewicza, zabrakło zaś m.in. tenisisty Ignacego Tłoczyńskiego, szachisty światowej sławy Mieczysława Najdorfa, sportowca i dziennikarza Radia Wolna Europa Wojciecha Trojanowskiego, czy też działacza PKOl oraz kilku związków sportowych w II Rzeczypospolitej gen. Kazimierza Glabisza). W końcu, w rozważaniach podniósł problem weryfikacji sportowców przez władze. W tym miejscu zwrócił uwagę na specyfikę ziem wcielonych w 1939 r. do Rzeszy i losy niektórych sportowców (np.głośna sprawa piłkarza Ernesta Wilimowskiego i nie mniej spektakularna boksera Szapsela Rotholca, który w czasie okupacji był policjantem w getcie warszawskim; dodałbym od siebie pominięty przykład Teodora Regedzińskiego z Łodzi, wielokrotnego uczestnika i medalisty olimpiad szachowych, po wojnie skazanego na długoletnie więzienie). Autor trafnie też podkreślił, iż ów problem wywołał ogromny rezonans szczególnie na Górnym Śląsku.

Rozdział drugi pt. „Od «drobnomieszczańskiej tradycji» w kierunku modelu radzieckiego (1946-1949)" traktuje o powolnym i konsekwentnie realizowanym przez komunistów procesie odchodzenia od przyjętego wcześniej modelu przedwojennego w zakresie nadzoru nad sportem i wychowaniem fizycznym. Pierwszym sygnałem wskazującym na zaostrzenie kursu wobec organizacji i klubów sportowych była likwidacja Towarzystwa Gimnastycznego „Sokół”, którego tradycja sięgała jeszcze XIX stulecia. Trzy lata później los „Sokoła” podzieliła YMCA, uznana za niebezpieczną dla polskiej młodzieży „organizację faszystowsko-burżuazyjną". Potem został rozwiązany Związek Polskich Związków Sportowych i po olimpiadzie w Londynie - jako „burżuazyjna pozostałość” - PKOl.Jest zrozumiałe, że likwidacji niektórych organizacji towarzyszyła reorganizacja Państwowego Urzędu Wychowania Fizycznego i Przysposobienia Wojskowego. Pasko zauważył, że taktyka komunistów w tym wypadku była przewrotna. $O$ ile dążyli oni do zmiany struktur organizacyjnych,o tyle początkowo nie zamierzali dokonać rewolucji kadrowych. Wprost przeciwnie - do PUWFiPW wprowadzili znanych przedwojennych działaczy i byłych sportowców, w tym m.in. Tadeusza Kuchara i Walentego Forysia. W niektórych związkach można było doszukać się nawet przedwojennych generałów, jak np. Władysław Bończa-Uzdowski w Polskim Związku Piłki Nożnej, jego prezes z lat 1928-1937.Z drugiej jednak strony na nieco niższych stanowiskach zostali ulokowani oficerowie polityczni z Wojska Polskiego, z dużym stażem komunistycznym sięgającym jeszcze niekiedy Komunistycznej Partii Polski. Tak więc Kucharowi towarzyszył początkowo Eugeniusz Zadrzyński, od lipca zaś 1946 r. gen. Eugeniusz Kuszko, który w latach wojny przebywał w Związku So- 
wieckim, natomiast po wojnie objął stanowisko pierwszego zastępcy szefa Głównego Zarządu Polityczno-Wojskowego Wojska Polskiego. Moim zdaniem można było znacznie rozwinąć ten problem o jeszcze jeden wątek, który niestety tylko sporadycznie pojawia się w całej pracy. Rzecz dotyczy tzw. sowietników (tego powszechnie już przyjętego przez historyków określenia Autor nie używa), czyli sowieckich oficerów i doradców cywilnych oddelegowanych do poszczególnych resortów (np. wojska, bezpieczeństwa, sprawiedliwości, gospodarki i nawet sportu). W polskim ruchu sportowym pierwszoplanowym sowietnikiem był niewątpliwie płk Apolinary Minecki, jedynie tu wzmiankowany. Z ustaleń Godlewskiego wynika, że był on „mroczną postacią” w kierownictwie polskiego sportu oraz działaczem kontrowersyjnym, zainteresowanym przede wszystkim piciem alkoholu i molestowaniem seksualnym sportsmenek. Zresztą zaraz po olimpiadzie w Helsinkach został odesłany do Związku Sowieckiego ${ }^{28}$.Z kolei Władysław Litmanowicz, który poznał Mineckiego jeszcze w ZSRS w czasie wojny, wspomina, że był osobą miłą i przychylną m.in. grze szachowej i to dzięki jego inicjatywie reprezentacja Polski wyjechała na olimpiadę szachową do Helsinek w $1952 \mathrm{r}^{29}$

W tej części rozważań wydaje się również konieczne umieszczenie jeszcze jednego ważnego zagadnienia, które uszło uwadze Autora. Sprawa dotyczy oddelegowania do związków sportowych wysokich oficerów Ministerstwa Bezpieczeństwa Publicznego i Wojska Polskiego, którzy niekiedy bez żadnej wiedzy i doświadczenia obejmowali wysokie stanowiska w zarządach związków. Ów problem prześledziłem na przykładzie Polskiego Związku Szachowego (sekcji szachowej Głównego Komitetu Kultury Fizycznej). W 1951 r. rozpoczął w nim działalność kpt. Litmanowicz, przedwojenny łódzki szachista niezłej klasy, po wojnie zaś oficer Informacji Wojskowej i sędzia (skazał m.in. na karę śmierci Wiesława Chrzanowskiego). Tę kadrową decyzję można było jeszcze jakoś zrozumieć. Natomiast ulokowanie w strukturach kierowniczych związku szachowego kpt. Emila Niewiarowskiego z pozoru wydawało się niezrozumiałe. Czytelne wydaje się natomiast wówczas, gdy prześledzimy jego biografię. Otóż Niewiarowski był oficerem MBP i skierowany do związku szachowego jako szef komisji organizacyjnej, zarządzał całą organizacją. Krótko rzecz ujmując, infiltrował środowisko szachistów w kraju oraz tych spoza Polski, którzy przyjeżdżali nad Wisłę na turnieje międzynarodowe.

Kolejne zmiany w Komitecie nastąpiły w 1949 r. Wówczas Kuchara zamienił Lucjan Motyka, były działacz PPS. Idąc tropem kadrowym, Autor wskazał również na wielokrotnie ponawiane przez komunistów próby idące w kierunku wymiany polskich członków w MKOl.Z odnalezionej przez Paskę dokumentacji w Archiwum MKOl wynika, iż polskim działaczom o komunistycznej proweniencji doskwierała przede wszystkim obecność Jerzego Lotha, profesora Uniwersytetu Warszawskie-

${ }^{28}$ P. Godlewski, Sport $w$ Polsce, s. 192-193.

${ }^{29}$ W. Litmanowicz, Nowe dykteryjki i ciekawostki szachowe, Warszawa 1983, s. 88-89. Szerzej ten wątek omówiłem w artykule: T. Wolsza, Olimpijczyk z partyjnego nadania? Droga Andrzeja Pytlakowskiego do drużyny olimpijskiej na szachowa olimpiadę w Helsinkach w 1952 r., , ,Glaukopis” 2014, 30, s. 192-205. 
go i członka Stronnictwa Demokratycznego. W jego miejsce komuniści zgłosili kandydatury Janusza Zarzyckiego (przewodniczącego Związku Młodzieży Polskiej) oraz Władysława Wolskiego, przedwojennego komunisty, Ministra Administracji Publicznej. Z uwagi na brak zainteresowania w MKOl tymi kandydaturami władze warszawskie przedstawiły kolejne: Motyki i Henryka Szemberga, który był m.in. adiutantem gen. Karola Świerczewskiego i charakteryzował się wręcz nieprawdopodobną niechęcią do działaczy z przedwojennym rodowodem (np. w stosunku do ppłk. dr. Włodzimierza Missiuro, więźnia sowieckiego z Pawliszczew Boru i Griazowca, od 1941 r. docenta na Polskim Wydziale Lekarskim Uniwersytetu w Edynburgu, po wojnie zaś profesora Uniwersytetu Łódzkiego). Te propozycje również nie zyskały akceptacji MKOl, z uwagi, jak to ustalił Autor, na nadal bardzo wysokie oceny pracy prof. Lotha.

Za niezwykle interesujący uznałbym fragment dotyczący sportu w propagandzie państwowej. Autor wyłowił kilku polskich wybitnych sportowców z przełomu lat czterdziestych i pięćdziesiątych, którzy z uwagi na osiągnięcia i dobry życiorys, z robotniczym lub chłopskim rodowodem, byli szczególnie stawiani jako wzór do naśladowania.W komunistycznej publicystyce eksponowano np. sukcesy i postać gimnastyczki Heleny Rakoczy oraz karierę znanej tenisistki Jędrzejowskiej, czołowej zawodniczki na świecie. Jak sądzę, wybór tej drugiej też nie był przypadkowy i nie tylko brał się z jej sukcesów sportowych i pochodzenia społecznego. Dodałbym do tych argumentów jeszcze jeden wątek, na który Autor nie zwrócił uwagi. Mam tu na myśli sprawę dwóch innych polskich tenisistów światowej sławy: Tłoczyńskiego i Czesława Spychały, żołnierzy 2. Korpusu gen. Władysława Andersa, którzy po wojnie pozostali na emigracji i z powodzeniem uczestniczyli w turniejach, np. w Wimbledonie w 1946 r. Sprawa ta wywoływała irytację w Warszawie, w kręgach nie tylko sportowych, ale przede wszystkim politycznych. Komuniści, przy pomocy polskiej ambasady w Londynie, bezskutecznie poprzez naciski dyplomatyczne próbowali spowodować usunięcie obu tenisistów z zawodów, argumentując, że reprezentują faszystowską armię gen. Andersa. Sprawę tę dość drobiazgowo relacjonował „Dziennik Polski i Dziennik Żołnierza”, ze zrozumiałych względów kibicujący emigracyjnym sportowcom. Jak sądzę, sława i sukcesy Jędrzejowskiej miały więc przesunąć w cień osiągnięcia jej przedwojennych kolegów oraz odwrócić uwagę społeczeństwa w kraju od polskiej powojennej emigracji politycznej, w tym od słynnego 2. Korpusu i jego szlaku bojowego.

Pozostając przy problematyce dotykającej spraw kraju i emigracji, chciałbym zwrócić uwagę na jeszcze jeden interesujący epizod, który wprawdzie nie został naświetlony w recenzowanej pracy, ale nieco wcześniej Pasko zajął się nim na marginesie jednego ze swoich artykułów. Mam tu na myśli osiągnięcia Wandy Szemplińskiej - rekordzistki świata w szybownictwie, o karierze której i jej zobowiązaniach w ramach współzawodnictwa pracy Autor dość dużo napisał w sygnalizowanym już artykule ${ }^{30}$. Temat był niewątpliwie godny uwzględnienia w omawianej monografii, zważywszy na biografię samej rekordzistki i jej ojca. W latach

${ }^{30}$ A. Pasko, Kobieta-sportowiec w propagandzie Polski Ludowej, s. 207-208. 
1951-1952 „Trybuna Ludu”, jak ustalił Autor, prezentowała Szemplińską jako wzór do naśladowania. Potem propagandziści zrezygnowali z wykorzystywania wizerunku tejże sportsmenki dla celów politycznych. Pasko tłumaczy to m.in. zbyt małą popularnością szybownictwa w Polsce. Nie jest wykluczone, że jest w tym trochę prawdy. W wypadku jednak Szemplińskiej doszły zapewne i inne względy, i to ważnej natury politycznej. Jej ojciec bowiem - Zygmunt Szempliński, używający pseudonimu Stanisław Klinga, był jednym z najbardziej znanych komentatorów politycznych w prasie emigracyjnej („Dziennik Polski i Dziennik Żołnierza”, „Myśl Polska” i „Orzeł Biały”). Zajmował się przede wszystkim problematyką gospodarczą w krajach za żelazną kurtyną oraz sprawami sowieckimi. Osobiście zaliczyłbym Szemplińskiego do czołowych emigracyjnych sowietologów ${ }^{31}$. Nie wyobrażam sobie, aby w Warszawie nie znano kulis emigracyjnej biografii ojca Szemplińskiej i to raczej one wykluczyły jego córkę z grona postaci prezentowanych i gloryfikowanych w peerelowskich mediach lat pięćdziesiątych.

Nie mniej interesująca wydaje się sprawa uczestnictwa Polski w Igrzyskach Bałkańsko-Środkowoeuropejskich w 1948 r., których pomysłodawcą była Jugosławia. Z uwagi na rodzący się konflikt pomiędzy Belgradem i Moskwą zawody zbojkotował Związek Sowiecki oraz pozostałe kraje bloku komunistycznego, w tym Polska.Jak podaje Autor, impreza została zawieszona, przedstawiciele zaś Rumunii domagali się natychmiastowego zlikwidowania tych igrzysk. Białostocki historyk prześledził w tym wypadku dokumentację PUWFiPW, z której wynika, iż z uwagi na spodziewany poziom zawodów owe igrzyska były dla polskich sportowców wręcz niezbędne. Władze polskiego sportu wiązały z tą rywalizacją duże nadzieje, tym bardziej iż współgospodarzem kolejnych miała być m.in.Polska.Z ustaleń Paski wynika również to, że dla przedstawicieli niektórych dyscyplin sportowych była to wręcz jedyna okazja do międzynarodowej rywalizacji. W związku z tym nie wywołuje zdziwienia przytoczony przez Autora fragment dokumentu: , Jak będą wyglądały kontakty sportowe z zagranicą - trudno jest w tej chwili powiedzieć, gdyż po odroczeniu Igrzysk Bałkańskich i Europy Środkowej, na których zasadniczo opierały się nasze zagraniczne kontakty, szereg planowanych imprez międzynarodowych nie doszło do skutku" (s.94). Ów wątek, z Jugosławią w roli głównej, można było, jak sądzę, rozbudować o kolejne przykłady, z których za najważniejszy uznałbym bojkot przez Związek Sowiecki i inne kraje znajdujące się pod sowiecką dominacją, pierwszej powojennej, w kolejności zaś już dziewiątej olimpiady szachowej w Dubrowniku w 1950 r. Honorowy patronat nad zawodami objął marszałek Josip Broz-Tito, z którym Stalin był wówczas skonfliktowany. Przyczyny absencji kilku krajów z Europy Środkowo-Wschodniej były zatem czytelne ${ }^{32}$.

${ }^{31}$ T. Wolsza, Za żelazna kurtyną. Europa Środkowo-Wschodnia, Związek Sowiecki i Józef Stalin w opiniach polskiej emigracji politycznej w Wielkiej Brytanii 1944/45-1953, Warszawa 2005. Por. również P. Wójtowicz, Obraz Związku Sowieckiego w ujęciu polskiej emigracji politycznej w Wielkiej Brytanii w latach 1945-1956, Warszawa 2008.

${ }^{32}$ W literaturze szachowej na temat absencji Polski w tej imprezie Autorzy wypowiadają się nader oszczędnie. Stanisław Gawlikowski (idem, Olimpiady szachowe 1924-1974, Warszawa 1978) stwierdził jedynie, że „w olimpiadzie nie wzięły udziału: ZSRR, CSR, 
Z opisywanych przez badacza przykładów w kolejnej części pracy wyłania się obraz ogromnego wręcz wpływu polityki na sport zarówno w sferze kształtowania kadr kierowniczych, kontaktów międzynarodowych, wykorzystywania sportowców do działalności propagandowej, jak również, co zabrzmi nieprawdopodobnie, przebiegu rywalizacji. Kierownictwo partii zakładało całkowitą kontrolę nad życiem sportowym. Ustalało reguły gry i rozdawało nagrody. Autor w tej ostatniej kwestii nie wykorzystał doskonałego przykładu, który rzuciłby światło na praktyki komunistów, jeśli chodzi o sprawę nagród i wyróżnień. Rzecz dotyczyła plebiscytu „Przeglądu Sportowego” w 1953 r. na najlepszych polskich sportowców. Plebiscyt nie doszedł do skutku, albowiem władze same przygotowały listę najlepszych sportowców i przesłały do redakcji. Sprawa zakończył się anulowaniem konkursu. Warto byłoby wyświetlić kulisy tej sprawy. Zachęcam więc Autora do zbadania problemu.

Z wydarzeń z lat pięćdziesiątych Autor ze zrozumiałych względów szczegółowo omówił kulisy udziału reprezentacji Polski na olimpiadzie w Helsinkach w 1952 r. oraz warszawskich mistrzostw Europy w boksie w 1953 r. W pierwszej kwestii podkreślił, że gdyby nie przyjazd do Helsinek reprezentacji Związku Sowieckiego, to Polska i inne kraje z sowieckiej strefy wpływów musiałyby zrezygnować z uczestnictwa w zawodach. Dodatkowo podkreślił, że z ekipą olimpijską wyjechała do Finlandii duża grupa opiekunów z resortu bezpieczeństwa. Natomiast w sprawie mistrzostw bokserskich wskazał na kompromitującą postawę polskich działaczy, którzy m.in. przepraszali delegację sowiecką za zwycięstwa polskich bokserów nad reprezentantami wschodnich sąsiadów. Dalej historyk omówił procedurę zmiany nazw klubów sportowych i związków, w tym Polskiego Związku Piłki Ręcznej (PZPR) na Polski Związek Koszykówki, Siatkówki i Szczypiorniaka (nie bacząc na złą konotację określenia szczypiorniak związanego z legionami Józefa Piłsudskiego). Znane od lat nazwy: „Wisła”, „Cracovia”, „Polonia”, „Warta”, „Legia” i „Lech” i in. z dnia na dzień stały się Gwardiami, Ogniwami, Kolejarzami, Włókniarzami, Górnikami, Budowlanymi i Związkowcami. Uczony przywołał w tym miejscu m.in. wypowiedź jednego z działaczy, ppłk. Tadeusza Dudy, który stwierdził: ,zniesienie starych nazw przyczyni się do ujednolicenia sportu. Nazwy stare są tradycjami wstecznictwa" (s. 121). W końcu przybliżył czytelnikom szerzej nieznany problem zainteresowań sportowych Bolesława Bieruta, który doceniał przede wszystkim sukcesy polskich sportowców poza granicami kraju, w tym nad zawodnikami z Europy Zachodniej. Dlatego też sugerował, aby Polacy rywalizowali w takich dyscyplinach, w których sukcesy wydawały się pewne. Po-

Węgry, Rumunia, Bułgaria, NRD i Polska, co oczywiście w poważnym stopniu osłabiło wagę, poziom i atrakcyjność dubrownickiej imprezy” (s. 119). W. Litmanowicz (op. cit.) nadmienił, iż „olimpiada, rozegrana w 1950 r. w Dubrowniku (Jugosławia), była przez wszystkie kraje demokracji ludowej zbojkotowana ze względów politycznych" (s. 85). Andrzej Filipowicz zaś (idem, Dzieje Polskiego Związku Szachowego do 1956 roku, Warszawa 2007) zanotował: „Nie dochodzi do skutku start Polski w olimpiadzie w Dubrowniku, rozgrywanej na przełomie sierpnia i września, gdyż kraje obozu socjalistycznego zbojkotowały Jugosławię, zgodnie z wytycznymi otrzymanymi z ZSRR" (s. 188). 
rażki wszakże dopuszczał, ale tylko nieznaczne. Zestawienie owych dyscyplin godnych zaufania obejmowało: boks, hokej na trawie, łucznictwo, szermierkę, wioślarstwo, siatkówkę, piłkę nożną, lekką atletykę, zapasy i podnoszenie ciężarów.Jeśli chodzi natomiast o rywalizację z zawodnikami z Europy Zachodniej, to zdaniem Bieruta Polacy bez obaw mogli rywalizować w boksie, lekkiej atletyce, pływaniu i szermierce. Ów wykaz, jak ustalił Autor, w dużej mierze zadecydował o międzynarodowych kontaktach polskich sportowców w pierwszej pięciolatce lat pięćdziesiątych XX w. Pierwszy sekretarz nie dożył natomiast sukcesu Stanisława Królaka w Wyścigu Pokoju w 1956 r., który, wbrew temu, co stwierdził Autor, nie odbył się latem, lecz tradycyjnie w maju. Wszak była to impreza powiązana z tzw. dniem zwycięstwa, obchodzonym w krajach za żelazną kurtyną 9 maja. Mimo tej usterki pragnę w tym miejscu zauważyć, że zagadnienia dotyczące Wyścigu Pokoju należy zaliczyć w recenzowanej książce do najlepiej opracowanych.

W rozdziale czwartym pt. „Zawiedzione nadzieje (1956-1970)” Pasko uwzględnił dwie sprawy. Podjął udaną próbę omówienia popaździernikowej demokratyzacji struktur kierowniczych polskiego sportu oraz zajął się nie mniej interesującym problemem sportowców amatorów i zawodowców w krajach za żelazną kurtyną, oczywiście na przykładzie Polski. Przede wszystkim dowiódł, iż zmiany w strukturach kierowniczych były pozorne, na czele bowiem GKKF pozostał Włodzimierz Reczek, który karierę rozpoczął jeszcze w okresie stalinizacji polskiego życia społeczno-politycznego, w 1952 r. Jak się wydaje, stanowisko zawdzięczał przyjaźni z Józefem Cyrankiewiczem. Autor skrupulatnie prześledził jego inicjatywy w drugiej połowie 1956 r. i doszedł do wniosku, że był sprytnym graczem, zarazem lubianym przez środowisko sportowe. Potwierdzili to historykowi m.in. świadkowie E. Duńska-Krzesińska, Andrzej Krzesiński, Franciszek Gąsienica-Groń i W. Zabłocki. W 1957 r. został reaktywowany Związek Polskich Związków Sportowych oraz dokonano istotnych zmian w składzie prezydium PKOl. Na czele organizacji stanął Reczek. Można pokusić się o konstatację, że od tej chwili stał się na wiele lat dyktatorem polskiego sportu. W końcu, w 1961 r., został członkiem MKOl. Tym samym zrealizował pomysł komunistów sięgający jeszcze $1948 \mathrm{r}$.

Jest zrozumiałe, że w tej części pracy Autor uwzględnił również problematykę dotykającą zagadnień sportu i polityki. Z uwagi na wojnę w Wietnamie Polska odwołała np. prestiżowy mecz lekkoatletyczny z USA, w zamian zaś odbyło się spotkanie ze Związkiem Sowieckim w Mińsku. Białostocki historyk szeroko uwzględnił w rozważaniach sukcesy polskich olimpijczyków w Rzymie, Tokio i Meksyku. Zważywszy na temat pracy, zagubił jedynie rzymską misję Glabisza, przedwojennego prezesa PKOl oraz działacza kilku związków sportowych. Generał nie tylko odwiedził polskich sportowców w Rzymie, lecz również wysłał list do kierownictwa PKOl z gratulacjami za olimpijskie sukcesy, czym wywołał niemałą konsternację wśród polskich działaczy ${ }^{33}$. Wyróżniłbym ponadto ustalenia Autora

33 G. Wieczorek, Misja generała Kazimierza Glabisza podczas Igrzysk Olimpijskich w Rzymie (1960), w: Magia sportu i słowa, s. 115-127. 
dotyczące imprez sportowych w 1966 r. w trakcie uroczystości tysiąclecia państwa polskiego i milenium chrztu. Okazało się, iż mecz piłkarski Polska-Węgry, który doszedł do skutku 3 maja 1966 r. w Chorzowie, pierwotnie był zaplanowany na termin kwietniowy. Władze polskie zwróciły się jednak z prośbą do samego Jánosa Kádára, aby zawody przełożyć na maj, i to dokładnie na dzień 3 maja. Wybór tej daty, jak trafnie zauważył Autor, nie był dziełem przypadku. Jest zrozumiałe, że mecz z byłymi wicemistrzami świata miał odciągnąć jakąś część społeczeństwa od wizyty w Częstochowie, w sanktuarium maryjnym. W tym miejscu zabrakło mi jednak jeszcze jednego epizodu piłkarskiego związanego z uroczystościami kościelnymi w Częstochowie. Autor mógł omówić kulisy meczu „Rakowa” Częstochowa z „Polonią” Bytom, który odbył się 1 maja 1966 r. w Częstochowie - tuż przed uroczystościami pod Jasną Górą. Intencje organizatorów były także jak najbardziej czytelne ${ }^{34}$.

Jeśli chodzi natomiast o sportowe wydarzenia z 1969 r., to białostocki badacz w rozważaniach uwzględnił oczywiście Wyścig Pokoju, z którym wszystkie kraje socjalistyczne miały wówczas poważny problem z uwagi na wcześniejszą agresję wojsk Układu Warszawskiego na Czechosłowację. Opisując wydarzenia, historyk pokazał, iż władze CSRS przygotowały alternatywną trasę wyścigu, z pominięciem Polski i NRD. Impreza w końcu odbyła się jednak po myśli władz polskich i niemieckich w granicach obu krajów, z krótką wizytą kolarzy w Czechosłowacji (na odcinku $112 \mathrm{~km}$ ). W tym miejscu Pasko przywołał szereg informacji na temat zachowania czechosłowackich kibiców, którzy m.in. rozsypywali pineski na trasie etapu i wrogo byli ustosunkowani do uczestników i organizatorów zawodów.

Rozdział piąty pt. „Między Monachium a Moskwą (1970-1980)” dotyczy okresu 1970-1980, czyli epoki Edwarda Gierka. Najważniejsze zmiany organizacyjne, jakie zaszły w tym okresie, obejmowały oddanie Głównego Komitetu Kultury Fizycznej i Turystyki pod kontrolę Polskiej Federacji Sportu. W późniejszym terminie GKKFiT zmienił nazwę na Główny Komitet Kultury Fizycznej i Sportu. Jednocześnie zostały ograniczone kompetencje PKOl. W 1973 r. Reczka na stanowisku przewodniczącego GKKFiT zmienił aktywista partyjny Kapitan.

Jak ustalił Autor, przed wyjazdem na olimpiadę do Monachium (1972) polscy działacze i dziennikarze przeszli specjalne przeszkolenie polityczne, z uwagi na fakt, iż igrzyska były zlokalizowane w mieście-siedzibie Radia Wolna Europa. W szkoleniu wykładowcy podkreślili m.in., iż to właśnie w Monachium przed laty powstała NSDAP. Historyk zwrócił również uwagę, że kilku dziennikarzy było tajnymi współpracownikami Służby Bezpieczeństwa. Przywołał tu m.in. nazwiska Mrzygłoda i Jana Ciszewskiego. Z nie mniejszym zainteresowaniem zajął się również olimpiadą w Moskwie. To zrozumiałe, gdyż cieniem na moskiewskich zawodach położyła się agresja wojsk sowieckich na Afganistan. To wydarzenie wywołało bojkot imprezy przez niektóre kraje Europy Zachodniej i Ameryki Północnej. Z moskiewską olimpiadą wiąże się również głośna sprawa Kozakiewicza, a w zasa-

${ }^{34}$ T. Wolsza, Częstochowa w latach 1957-1970, w: Częstochowa. Dzieje miasta i Klasztoru Jasnogórskiego, t. 4, red. K. Kersten, Częstochowa 2007, s. 177. 
dzie jego słynnego gestu po udanym skoku. Z ustaleń Autora wynika, iż ambasador Związku Sowieckiego w Polsce domagał się dyskwalifikacji sportowca i odebrania mu złotego medalu. $Z$ tej części pracy wyróżniłbym jeszcze jeden fragment dotyczący nagród dla sportowców startujących w olimpiadach, mistrzostwach Europy i świata (za złote medale wypłacano w zależności od rangi zawodów od 70 do 1000 dolarów USA). Inna sprawa, że nie zawsze mistrzowie otrzymywali całą ustaloną wcześniej kwotę. Szkoda, iż Autor nie przywołał w tym miejscu historii Fortuny mistrza olimpijskiego z Sapporo, który otrzymał nagrodę pomniejszoną o połowę. Pozostałe pieniądze, jak można się domyślić, trafiły do kieszeni działaczy.Z ustaleń Paski wynika natomiast, że kieszonkowe polskiego olimpijczyka opiewało na kwotę około 2 dolarów dziennie (w innych krajach socjalistycznych od 3-4 dol.). Skromne kieszonkowe powodowało różnego rodzaju afery z udziałem sportowców, którzy trudnili się przemytem deficytowych towarów i nielegalnym handlem nimi oraz wymianą walut. Ten aspekt również został zilustrowany w monografii kilkoma przykładami, jak chociażby spektakularną sprawą wręcz bohatera narodowego - kolarza Królaka (ośmielił się wygrać wyścig z kolarzami sowieckimi), którego w końcu władze zawiesiły i zniechęciły do wyczynowego uprawiania kolarstwa.

Ostatni rozdział pracy pt. „W dobie kryzysu (1980-1989)” składa się z dwóch części. Pierwsza odnosi się do pozorowanych zmian w strukturach organizacyjnych instytucji odpowiadających za sport i turystykę. Słusznie Autor podkreślił w tym miejscu, że stan wojenny na kilka lat opóźnił jakiekolwiek zmiany na lepsze. Dopiero w 1987 r. GKKFiT został zastąpiony przez powołany do życia Komitet do spraw Młodzieży i Kultury Fizycznej pod prezesurą Aleksandra Kwaśniewskiego. Historyk sporo uwagi poświęcił sprawie weryfikacji dziennikarzy, w tym zajmujących się tematyką sportową. Wskazał, że pracę stracili wówczas m.in. Tomasz Hopfer i Krzysztof Wyrzykowski. Wydaje się również, że ów wątek można było nieco rozwinąć o udział dziennikarzy sportowych w procesie likwidacji Stowarzyszenia Dziennikarzy Polskich. Sprawa dotyczyła m.in. Żemantowskiego i Mrzygłoda. Z innych interesujących zagadnień w tej części pracy wskazałbym na problem bojkotu igrzysk olimpijskich w Los Angeles w 1984 r. przez kraje Europy Środkowo-Wschodniej (z wyjątkiem Rumunii), sprawę udziału polskich piłkarzy w mistrzostwach świata w Hiszpanii i Meksyku i związanych z tym transmisji telewizyjnych z poleceniem unikania za wszelką cenę haseł i transparentów na temat NSZZ „Solidarność” (zabrakło mi tu jednak odwołań do artykułu Krzysztofa Łoniewskiego) ${ }^{35}$ oraz Wyścigu Pokoju w 1986 r. z etapem w Kijowie po katastrofie w Czarnobylu. Przy omawianiu ostatniej kwestii Autor ustalił, że wicepremier Waldemar Świrgoń w długich nocnych rozmowach namawiał polskich kolarzy do udziału w zawodach, grożąc konsekwencjami nie tylko wobec samych sportowców, ale i ich rodzin. Narrację w tym miejscu można było wzbogacić o ustalenia Łukasza Karolewskiego z artykułu z „Dziejów Najnowszych” dotyczącego techniki

${ }^{35}$ K. Łoniewski, Mundial Meksyk '86. Polscy piłkarze w otoczeniu esbeków, w: Nieczysta gra, s. 111-129. 
ukrywania prawdy o skali katastrofy, w tym na temat Wyścigu Pokoju. Z badań,jakie historyk ten przeprowadził w dokumentacji Głównego Urzędu Kontroli Prasy, Publikacji i Widowisk, wynika, iż władze PRL zacierały w możliwie najszerszej skali skojarzenie imprezy sportowej z katastrofą. Tylko nieliczne informacje na ten temat docierały do czytelników prasy codziennej, najczęściej z powodu nieuwagi cenzorów (np. na temat paniki w kraju, wpływającej na psychikę i samopoczucie sportowców). Karolewski słusznie też podkreślił, że „Władze nie mogły się przyznać, że kolarze mieli własnym zdrowiem zaświadczyć, że w Czarnobylu przydarzyła się jedynie drobna awaria" ${ }^{\prime 36}$.

W konkluzji należy stwierdzić, iż książka Artura Paski nie tylko wypełnia lukę w krajowej historiografii, ale i pobudza do refleksji oraz dalszych badań dotyczących problemów z pogranicza sportu i polityki w Polsce w latach 1945-1989.

\section{Links between Politics and Sport in the People's Republic of Poland}

Sport wyczynowy w polityce państwa 1944-1989 (Kraków 2012), a book by Artur Pasko, is the first successful Polish attempt at an examination of sport and politics in post-war Poland to 1989. The author referred to all-sided sources of assorted origin, with pride of place given to archival research and oral history sources. The publication is composed of six chapters, whose inner caesurae are political and sports events: 1946, 1949, 1956, 1970 and 1980. The years 1956 and 1980 refer to important political and sports episodes (Polish October '56, the Olympic Games in Melbourne, the political crisis of 1980 and the Olympic Games in Moscow). In turn, the 1946 and 1949 caesurae denote essential moments in the history of sport, or rather the administration of physical culture, tourism, and military training. During this period, activists of the Polish Workers' Party and, subsequently, the Polish United Workers' Party devised a model of total control over competitive sport in Poland by entrusting it to trustworthy people with a communist lineage. The author discussed comprehensively a number of important motifs: the organisational structure and activists of such central institutions as the Polish Olympic Committee, the State Office of Physical Education and Military Defence, the Central Committee for Physical Culture, the Central Committee for Physical Culture and Sport, the Central Committee for Physical Culture and Tourism, the Polish Sport Federation and the Committee of Youth and Physical Culture; sport in the propaganda of People's Poland; relations between the Polish Olympic Committee and the International Olympic Committee; amateur and professional sport in countries beyond the Iron Curtain, and the invigilation of sportsmen and activists by the special services of People's Poland.

Translated by Aleksandra Rodzińska-Chojnowska

${ }^{36}$ Ł. Karolewski, Propagandowe techniki ukrywania katastrofy w Czarnobylu przez władze polskie, DN 2011, 2, s. 127. 